\title{
FEATURES OF CYTOKINE STATUS IN PATIENTS WITH CHRONIC EBV-INFECTIONS
}

\author{
Olga Sorokina ${ }^{1,2}$, Yaroslav Kolesnyk ${ }^{3}$, Svitlana Malanchuk ${ }^{1}$, Oleksander Kozlov ${ }^{1}$, Olesya Hololobova ${ }^{1}$ \\ ${ }^{1}$ V. N. Karazin Kharkiv National University, 6 Svobody Sq., Kharkiv, 61022, Ukraine, \\ e-mail: med@karazin.ua \\ ${ }^{2}$ Mechnikov Institute of microbiology and immunology, Pushkinska St. 14, Kharkiv, 61057, Ukraine, \\ e-mail: imiamn@ukr.net \\ ${ }^{3}$ Kharkiv National Medical University, 4 Nauky Avenue, Kharkiv, 61022, Ukraine, \\ e-mail: intercoop@knmu.kharkov.ua
}

Infections caused by EBV are the most common and occupy an important place in the structure of herpes aetiology diseases.

The purpose of this work was to study the characteristics of the cytokine status in patients with chronic EBV infection, depending on the level of viral replication.

We examined 78 patients with chronic EBV infection, the main clinical manifestations of which were various immunopathological and immunodeficiency states: Group I - with low, Group II - with medium, Group III - with a high degree of viral replication. The Tiff method was used using the Vector-Best reagent kits (Novosibirsk, Russia) to study the cytokine profile in the serum of patients with EBV infection. The determination of alpha and gamma fractions of serum interferon was carried out using the ELISA method by means of the ProCon IF2 plus reagent kit manufactured by Protein Contour LLC (St. Petersburg, Russia).

As a result of a study of the cytokine status in patients with chronic EBV infection, it was found that in all three groups there was a significant increase in both pro-inflammatory (IL-1 $\beta$, IL-6, TNF- $\alpha$ ) and antiinflammatory cytokines (IL-10, IL 4, TGF $\beta 1$ ). However, anti-inflammatory cytokinemia was more compensated in group I patients compared with patients in groups II and III. A decrease in IFN- $\alpha$ and IFN- $\gamma$ was detected in all patients with chronic EBV infection while studying the interferon status. A correlation was found between the level of viral replication and a decrease in the level of IFN- $\alpha$ and IFN- $\gamma$.

The identified features of the cytokine status in patients with chronic EBV infection can be used to optimize therapy and help develop a differentiated approach to the immunocorrection of these patients, depending on the level of viral replication.

KEY WORDS: interferon, interleukins, cytokines, chronic EBV infection, viral replication level

\section{ОСОБЛИВОСТІ ЦИТОКІНОВОГО СТАТУСУ У ХВОРИХ НА ХРОНІЧНУ ВЕБ-ІНФЕКЦЮЮ}

\author{
Сорокіна О. Г. ${ }^{1,2}$, Колесник Я. В. ${ }^{3}$, Маланчук С. Г. ${ }^{1}$, Козлов О. П. ${ }^{1}$, Гололобова О. В. \\ ${ }^{1}$ Харківський національний університет імені В. Н. Каразіна, пл. Свободи, 6, м. Харків, 61022, \\ Україна \\ 2 ДУ «Інститут мікробіології та імунології ім. І. І. Мечникова НАН України», вул. Пушкінська, 14, \\ м. Харків, 61057, Україна \\ ${ }^{3}$ Харківський національний медичний університет, пр. Науки, 4, м. Харків, 61022, Україна
}

Інфекції викликані ВЕБ $є$ найбільш поширеними і займають важливе місце в структурі захворювань герпесвірусной етіології.

Метою даної роботи було вивчити особливості цитокінового статусу у хворих на хронічну ВЕБінфекцію, в залежності від рівня вірусної реплікації.

Нами було обстежено 78 пацієнтів з хронічною ВЕБ-інфекцією, основними клінічними проявами в яких були різні іммунопатологичні і імунодефіцитні стани: I група - 3 низьким ступенем вірусної реплікації, II група - із середнім ступенем вірусної реплікації, III група - 3 високим ступенем вірусної реплікації. Для дослідження цитокінового профілю в сироватці крові хворих на ВЕБ-інфекцію використовували метод тІФА з використанням наборів реагентів ЗАТ «Вектор-Бест» (Новосибірськ, Росія). Визначення фракцій сироваткового інтерферону альфа та гамма здійснювали за допомогою твердофазного імуноферментного методу 3 використанням набору реагентів ProCon IF2 plus виробництва ТОВ «Протеїновий контур» (Санкт-Петербург, Росія). 
За результатами дослідження цитокінового статусу у хворих на хронічну ВЕБ-інфекцію було виявлено, що в усіх трьох групах відзначалося суттєве підвищення як прозапальних (ІЛ-1 $\beta$, ІЛ-6, ФНП- $\alpha$ ), так і протизапальних цитокінів (ІЛ-10, ІЛ-4, ТФР $\beta 1)$. Однак, протизапальна цитокінемія була у пацієнтів I групи більш компенсованою у порівнянні з пацієнтами II та III груп. При досліджені інтерферонового статусу було виявлено зниження ІФН- $\alpha$ та ІФН- $\gamma$ в усіх хворих на хронічну ВЕБінфекцію. Було виявлено кореляційний зв'язок між рівнем реплікації вірусу та зниженням рівнем ІФН$\alpha$ та ІФН- $\gamma$. Виявлені особливості цитокінового статусу у хворих хронічною ВЕБ-інфекцією, в залежності від рівня вірусної реплікації, можуть бути використані для оптимізації терапії та допоможуть розробити диференційований підхід до імунокорекції таких пацієнтів.

КЛЮЧОВІ СЛОВА: інтерферон, інтерлейкіни, цитокіни, хронічна ВЕБ-інфекція, рівень реплікація вірусу

\section{ОСОБЕННОСТИ ЦИТОКИНОВОГО СТАТУСА У БОЛЬНЫХ ХРОНИЧЕСКОЙ ВЕБ-ИНФЕКЦИЕЙ}

Сорокина О. Г. ${ }^{1,2}$, Колесник Я. В. ${ }^{3}$, Маланчук С. Г. $^{1}$, Козлов А. П. ${ }^{1}$, Гололобова О. В. ${ }^{1}$

${ }^{1}$ Харьковский национальный университет имени В. Н. Каразина, пл. Свободы, 6, г. Харьков, 61022, Украина

${ }^{2}$ ГУ «Институт микробиологии и иммунологии им. И. И. Мечникова НАН Украины», ул. Пушкинская, 14, г. Харьков, 61057, Украина

${ }^{3}$ Харьковский национальный медицинский университет, пр. Науки, 4, г. Харьков, 61022, Украина

Инфекции, вызванные ВЭБ, являются наиболее распространенными и занимают важное место в структуре заболеваний герпесвирусной этиологии.

Целью данной работы было изучить особенности цитокинового статуса у больных хронической ВЭБ-инфекцией, в зависимости от уровня вирусной репликации.

Нами было обследовано 78 пациентов с хронической ВЭБ-инфекцией, основными клиническими проявлениями у которых были разные иммунопатологические и иммунодефицитные состояния: I группа - с низкой, II группа - со средней, III группа - с высокой степенью вирусной репликации. Для исследования цитокинового профиля в сыворотке крови больных ВЭБ-инфекцией использовали метод Тифа с использованием наборов реагентов ЗАО «Вектор-Бест» (Новосибирск, Россия). Определение фракций сывороточного интерферона альфа и гамма осуществляли с помощью твердофазного иммуноферментного метода с использованием набора реагентов ProCon IF2 plus производства ООО «Протеиновый контур» (Санкт-Петербург, Россия).

В результате исследования цитокинового статуса у больных хронической ВЭБ-инфекцией было выявлено, что во всех трех группах отмечалось существенное повышение как провоспалительных (ИЛ-1 $\beta$, ИЛ-6, ФНО- $\alpha$ ), так и противовоспалительных цитокинов (ИЛ-10, ИЛ 4, ТФР $\beta 1$ ). Однако противовоспалительная цитокинемия была у пациентов I группы более компенсированной по сравнению с пациентами II и III групп. При исследовании интерферонового статуса было выявлено снижение ИФН- $\alpha$ и ИФН- $\gamma$ у всех больных хронической ВЭБ-инфекцией. Была обнаружена корреляционная связь между уровнем репликации вируса и снижением уровнем ИФН- $\alpha$ и ИФН- $\gamma$.

Выявленные особенности цитокинового статуса у больных хронической ВЭБ-инфекцией, в зависимости от уровня вирусной репликации, могут быть использованы для оптимизации терапии и помогут разработать дифференцированный подход к иммунокоррекции таких пациентов.

КЛЮЧЕВЫЕ СЛОВА: интерферон, интерлейкины, цитокины, хроническая ВЭБ-инфекция, уровень репликация вируса

\section{INTRODUCTION}

Every year, the impact of adverse environmental factors increases on the body and, particularly on the immune system. In the modern world, infectious diseases occupy a leading place in human pathology [1]. Among the numerous factors that directly affect the immune system, special attention is paid to herpesvirus infections. Nowadays there is a tendency for the diseases caused by herpesviruses to spread widely [2-3].

The Epstein-Barr virus (EBV) belongs to the Herpesviridae family. Infections caused by this virus are the most widespread and occupy an important place in the structure of herpesvirus aetiology diseases. This is due to the high degree of infection of the population 
all over the world, as specific antibodies to this virus are found in almost $95 \%$ of the adult population [4-5]. Active proliferation of the virus in all organs and systems that have lymphoid tissue, leads to structural changes, which has a negative impact on the whole body [6]. EBV has multiple mechanisms of immunosuppression and protection from the host's immune response that can lead to the formation of a chronic viral infection and immunological disorders deepening [7]. It is also established that EBV violates the mechanisms of the immune response, suppresses the production of interferons (INFs), blocks the mechanisms of apoptosis. A secondary immunodeficiency is formed on the basis of these disorders, that promotes the development of autoimmune and tumour processes in genetically predisposed individuals. The study of diseases caused by EBV is relevant due to the life-span persistence of the virus in the human body, the potential for oncogenicity, and the ability to reactivate autoimmune diseases, to damage the heart, kidneys, joints, and others [2, 8-9].

Data obtained from many studies suggest a violation of the interferon chain of immunity while herpesvirus infections. Low content of these cytokines does not provide sufficient antiviral effect. In this regard, the study of indicators of immunity provided by interferons becomes particularly relevant in patients with chronic EBV infection [10].

Non-specific factors of protection, including interferons are the first line response while infecting the human body and they induce the increase of the body's resistance. The course and effects of the disease depend on the rate of INF system involvement in the process of INF antiviral protection. The untimely or reduced production of its own IFN, as a rule, leads to the chronization of the WEB infection. Interferon-alpha (IFN- $\alpha$ ) is the most active in the early phase of the EBV infection, when even the EBV antigens do not spred beyond the cell, and products of specific antibodies are not possible. $\alpha$-IFN prevents the spread of EBV by providing the antiviral function from the site of penetration into the body to distant organs and systems.

Interferon gamma (IFN- $\gamma)$ is an indicator of activity of the cellular immunity. It also has an antiproliferative effect, which is relevant in case of EBV infection, which is an antigen of many tumours and neoplasia. However it is known that EBV is capable of suppressing the IFN- $\gamma$ synthesis and thus suppressing cellular immunity, creating conditions for its lifelong persistence [11].

\section{OBJECTIVE}

The purpose of this work was to study the cytokine status features in patients with chronic EBV infection, depending on the level of viral replication.

\section{MATERIALS AND METHODS}

We examined 78 patients with chronic EBV infection, the main clinical manifestations of which were various immunopathological and immunodeficient conditions. All patients in the main group were divided into 3 groups according to the level of viral replication: Group I - with low degree of viral replication, composed of 25 people (11 men and 14 women); Group II - with an average degree of viral replication, included 27 patients (12 men and 15 women); Group III - with a high degree of viral replication, consisted of 26 patients (12 men and 14 women). The age of patients ranged from 19 to 57 years (mean age was 33 years \pm 11.7 years). The control group consisted of 20 practically healthy people aged from 20 to 35 years.

The work was performed at the Department of General and Clinical Immunology and Allergology of the Medical Faculty of the V. N. Karazin Kharkov National University and clinical bases of the department: Regional Clinical Infectious Hospital in Kharkiv and the Clinical Hospital «City Polyclinic № 6», as well as on the basis of the SI «I. I. Mechnikov Institute of Microbiology and Immunology of the National Academy of Medical Sciences of Ukraine» in the period of 2014-2018 in the framework of the research topic: «The study of the role of immune, autoimmune and metabolic disorders in pathogenesis and the consequences of the infection process caused by herpesviruses», state registration number 0112U005911. The analysis of samples and their technical implementation was carried out in the clinical diagnostic laboratory of the Regional Clinical Infectious Hospital, part of the analyses were carried out in the laboratories «Virolos» and «Analitika». The TIFA method was used by means of the 
reagent kits of CJSC Vector-Best (Novosibirsk, Russia) using the manufacturer's instructions to investigate the cytokine profile in the blood serum of patients with EBV infection. Determination of alpha and gamma fractions of serum interferons was performed using a solid phase immunoassay method by means of the set of ProCon IF2 plus reagents manufactured by the Protein Contour LLC (St. Petersburg, Russia).
The statistical processing of the results of the study was conducted using the STATISTICA 10.0 statistical software package.

\section{RESULTS AND DISCUSSION}

IFN- $\alpha$ level was reduced in patients with chronic WEB infection with different levels of virus replication in all studied groups compared with the control group (tab. 1).

The content of IFN in serum in patients with chronic WEB infection

Table 1

\begin{tabular}{|c|c|c|c|c|c|}
\hline Indicator & I group & II group & III group & Control group & $\mathrm{p}$ \\
\hline IFN- $\alpha, \mathrm{pg} / \mathrm{ml}$ & $30,3 \pm 1,7$ & $27,5 \pm 1,9$ & $25,6 \pm 1,8$ & $32,4 \pm 2,3$ & $\mathrm{p}<0,001$ \\
\hline IFN- $\gamma, \mathrm{pg} / \mathrm{ml}$ & $37,1 \pm 1,8$ & $35,3 \pm 1,6$ & $25,4 \pm 1,7$ & $38,2 \pm 1,6$ & $\mathrm{p}<0,001$ \\
\hline
\end{tabular}

Thus, IFN- $\alpha$ was $30.3 \pm 1.7 \mathrm{~g} / \mathrm{ml}$ in I group patients, in group II $-27.5 \pm 1.9 \mathrm{~g} / \mathrm{ml}$, in group III $-25.6 \pm 1.8 \mathrm{~g} / \mathrm{ml}$. Thus, there was a correlation between the level of viral replication and a decrease in the level of IFN$\alpha$ in chronic EBV infection. Possibly, EBV conversion from a latent state and its replication (reactivation of $\mathrm{EBV}$ infection) occurred under favourable conditions. A significant decrease in IFN- $\alpha$ and, as a consequence, a significant inhibition of antiviral defence, contributed to the accumulation of an active infectious agent that was actively multiplying.

According to many studies, in the majority of patients with acute EBV infection, a significant increase in IFN- $\gamma$ levels is usually observed in comparison with relatively healthy people. This indicates cellular immunity level and its predominance over the humoral link. Probably, therefore, in many cases, the acute form of the EBV infection ends with a rapid and, as a rule, complete recovery [12-13].
Among our patients with chronic forms of EBV infection, IFN- $\gamma$ was decreased in all studied groups compared with the control group. Thus, IFN- $\gamma$ was $37.1 \pm 1.8 \mathrm{pg} / \mathrm{ml}$ in group I patients, in group II patients $-35.3 \pm$ $1.6 \mathrm{pg} / \mathrm{ml}$, in group III patients $-25.4 \pm 1.7$ $\mathrm{pg} / \mathrm{ml}$. So, it is probably the IFN- $\gamma$ deficiency that led to protracted forms of infection with possible latent (for several years), or recurrent course. Probably the decrease in the content of IFN- $\gamma$ may be considered as one of the indicators of prolonged EBV infection.

It was found an increase in all indicators in all three groups (I, II, III) compared to the control group during the studying of the content of cytokines in blood serum of patients with chronic EBV infection, but these changes, had their own characteristics due to the level of replication of the virus (tab. 2). A higher anti-inflammatory cytokinemia and a deeper cytokine imbalance were recorded in patients of groups II and III compared with patients in group I.

The content of the main serum cytokines in patients with chronic EBV

Table 2

\begin{tabular}{|c|c|c|c|c|c|}
\hline Indicator & I group & II group & III group & Control group & $\mathrm{p}$ \\
\hline IL-1 $\beta, \mathrm{pg} / \mathrm{ml}$ & $59,1 \pm 2,1$ & $56,4 \pm 2,4$ & $56,3 \pm 2,3$ & $29,5 \pm 1,9$ & $\mathrm{p}<0,001$ \\
\hline IL-6, pg/ml & $91,2 \pm 2,1$ & $100,3 \pm 2,7$ & $104,4 \pm 3,6$ & $39,2 \pm 1,7$ & $\mathrm{p}<0,001$ \\
\hline TNF- $\alpha, \mathrm{pg} / \mathrm{ml}$ & $52,8 \pm 2,4$ & $62,4 \pm 2,2$ & $65,7 \pm 2,8$ & $32,6 \pm 1,8$ & $\mathrm{p}<0,001$ \\
\hline IL-2, pg/ml & $78,1 \pm 2,5$ & $68,4 \pm 2,4$ & $68,3 \pm 2,6$ & $40,2 \pm 2,1$ & $\mathrm{p}<0,001$ \\
\hline IL-10, pg/ml & $91,3 \pm 1,8$ & $88,3 \pm 2,1$ & $88,2 \pm 1,9$ & $19,1 \pm 1,5$ & $\mathrm{p}<0,001$ \\
\hline IL-4, pg/ml & $80,3 \pm 2,3$ & $75,6 \pm 2,6$ & $75,5 \pm 2,2$ & $21,2 \pm 1,7$ & $\mathrm{p}<0,001$ \\
\hline TGF $\beta 1, \mathrm{pg} / \mathrm{ml}$ & $172,4 \pm 3,1$ & $166,5 \pm 2,9$ & $166,3 \pm 2,2$ & $58,3 \pm 2,2$ & $\mathrm{p}<0,001$ \\
\hline
\end{tabular}


Thus, there was a more pronounced increase in IL-1 $1 \beta(59.1 \pm 2.1 \mathrm{pg} / \mathrm{ml})$ in case of the group I than in patients in groups II and III $(56.4 \pm 2.6 \mathrm{pg} / \mathrm{ml}$ and $56.3 \pm 2.3 \mathrm{pg} / \mathrm{ml}$, respectively) in comparison with the control group $(29.5 \pm 1.9 \mathrm{pg} / \mathrm{ml})$.

It was found during the study that IL-6 increase was observed in all patients with chronic EBV infection in comparison with the control group, but this indicator increased to a greater extent in patients of groups II and III $(100.3 \pm 2.7 \mathrm{pg} / \mathrm{ml}$ and $104.4 \pm 3.6 \mathrm{~kg} / \mathrm{ml}$, respectively). IL-6 was at $91.2 \pm 2.1 \mathrm{pg} / \mathrm{ml}$ in patients of group I, while in the control group it was $39.2 \pm 1.7 \mathrm{pg} / \mathrm{ml}$.

The level of TNF- $\alpha$ was elevated in all patients with chronic EBV infection compared to the control group, but it was higher in patients of groups II and III (62.4 \pm $2.2 \mathrm{~g} / \mathrm{ml}$ and $65.7 \pm 2.8 \mathrm{~g} / \mathrm{ml}$ in accordance). In patients of Group I, the FNP- $\alpha$ was $52.8 \pm$ $2.4 \mathrm{pg} / \mathrm{ml}$ and in the control group it was 32.6 $\pm 1.8 \mathrm{pg} / \mathrm{ml}$.

It is known that IL-2 is an important factor in the activation of immune cells and the development of a full-fledged immune response [14-16]. IL-2 levels were also elevated in all patients with chronic EBV infection, but this increase was not as significant as an increase in IL-1, IL-6 and FNP- $\alpha$ levels. Thus, IL-2 levels were higher $(78.1 \pm 2.5 \mathrm{pg} / \mathrm{ml})$ in group I patients than in patients of groups II and III $(68.4 \pm 2.4 \mathrm{pg} / \mathrm{ml}$ and $68.3 \pm 2.6 \mathrm{pg} / \mathrm{ml}$, respectively). In the control group, IL-2 was at $40.2 \pm 2.1 \mathrm{pg} / \mathrm{ml}$.

Concentration of IL-10 in serum was elevated in all patients with chronic EBV infection compared to control group. However, IL-10 levels increased to a greater extent $(91.3 \pm 1.8 \mathrm{pg} / \mathrm{ml})$ in group I patients, compared with patients in groups II and III $(88.3 \pm 2.1 \mathrm{pg} / \mathrm{ml}$ and $88.2 \pm 1.9 \mathrm{pg} / \mathrm{ml}$, respectively). In the control group, this indicator was $19.1 \pm 1.5 \mathrm{pg} / \mathrm{ml}$.

The level of IL-4 was elevated in all patients with chronic EBV infection compared to the control group, but it reached much higher figures $(80.3 \pm 2.3 \mathrm{~g} / \mathrm{ml})$ in group I patients, compared to patients of groups II and III $(75.6 \pm 2,6 \mathrm{pg} / \mathrm{ml}$ and $75.5 \pm$ $2.2 \mathrm{pg} / \mathrm{ml}$, respectively). In the control group, this figure was $21.2 \pm 1.7 \mathrm{pg} / \mathrm{ml}$.

The concentration of TGF $\beta 1$ was elevated in all patients with chronic EBV infection compared to the control group, but in patients of group I it level increased greater (172.4 \pm $3.1 \mathrm{pg} / \mathrm{ml}$ ), compared to patients of groups II and III $(166.5 \pm 2.9 \mu \mathrm{g} / \mathrm{ml}$ and $166.3 \pm 2.2$ $\mu \mathrm{g} / \mathrm{ml}$, respectively). This indicator was 58.3 $\pm 2.2 \mathrm{pg} / \mathrm{ml}$ in the control group.

Thus, anti-inflammatory cytokinemia was more compensated in patients of group I, compared with patients of groups II and III, as indicated by the ratio of proinflammatory and anti-inflammatory cytokines. It is known that anti-inflammatory cytokines are involved in limiting the inflammatory response, inhibit the secretion of proinflammatory cytokines, and reduce the damaging effect of inflammation on tissues [17-20].

\section{CONCLUSIONS}

Thus, our study of cytokine status in patients with chronic EBV infection showed that a significant increase in all three groups in both proinflammatory (IL-1 $\beta$, IL-6, FNP$\alpha)$ and anti-inflammatory cytokines (IL-10, IL-4, TFR $\beta 1$ ). However, the following features were revealed depending on the level of viral replication: elevation of IL-1 $\beta$, IL-10, IL-4, TFR $\beta 1$ to a greater extent was observed in patients of group I, compared to patients in groups II and III, in which IL-6, FNP- $\alpha$ prevailed. Thus, anti-inflammatory cytokinemia was more compensated in patients group I compared to patients of groups II and III, as shown by the ratio of proinflammatory and anti-inflammatory cytokines. IL-2 levels were also elevated in all patients with chronic EBV infection, but this increase was not as significant as the increase in other cytokines levels, which in turn affected the process of activation of immune-competent cells and prevented the formation of a complete immune response.

IFN- $\alpha$ and IFN- $\gamma$ levels were decreased in all patients with chronic EBV infection when interferon status was studied. A correlation was found between the level of viral replication and a decrease in IFN- $\alpha$ and IFN- $\gamma$ levels. A significant decrease in IFN- $\alpha$ contributed to significant inhibition of antiviral defence, which in turn effected the accumulation of an active infectious agent that was actively multiplying. The IFN- $\gamma$ deficiency did not allow forming a sufficient immune response and contributed to the development of a chronic form of infection. Probably the decrease in the content of IFN- $\gamma$ may be considered as one of the indicators of 
the prolong course of EBV infection and the development of chronic forms of $\mathrm{EBV}$ infection.

\section{PROSPECTS FOR FUTURE STUDIES}

The revealed features of cytokine status in patients with chronic EBV infection can be used to optimize therapy depending on the level of viral replication and will help to develop a differentiated approach to immune correction of such patients.

\section{REFERENCES}

1. Kliniko-laboratorni osobly`vosti perebigu infekcijnogo mononukleozu u dorosly`x / P. P. Kish., G. M. Koval`, V. O. Petrov [ta in.] // Naukovy`j visny`k Uzhgorods`kogo universy`tetu. - 2013. - T. 2. No. 47. - S. 139-144.

2. Kan N. Yu. Znachenie persistiruyuschey gerpesvirusnoy infektsii $v$ formirovanii vtorichnogo immunodefitsita u chasto boleyuschih detey // Detskie infektsii: Nauch.-prakt. zhurn. assots. pediatrovinfektsionistov. - M.: OOO «Diavaks», 2008. - No. 2. - S. 66-67.

3. Lan K., Luo M. H. Herpesviruses: epidemiology, pathogenesis, and interventions. - 2017.

4. Smatti M. K. et al. Epstein-Barr virus epidemiology, serology, and genetic variability of LMP-1 oncogene among healthy population: an update // Frontiers in oncology. - 2018. - T. 8.

5. Bodnar V. A. Udoskonalennya diagnosty`ky xronichny`x form infekciyi, zumovlenoyi virusom Epshtejna-Barr // Problemy` ekologiyi i medy`cy`ny` - 2013. - T.2. - No. 5-6. - S. 9-15.

6. Dambaeva S. V., Mazurov D. V., Klimova S. V. Otsenka osnovnyih parametrov immunnoy sistemyi s pomoschyu protochnoy lazernoy tsitometrii // Allergiya i immunologiya. - 2002. - T.3. - No. 3. S. 371-379.

7. Sorokina O. G. Doslidzhennya klity`nnogo imunitetu u xvory`x na xronichnu VEB-infekciyu // Imunologiya ta alergologiya: nauka i prakty`ka. - 2018. - No. 3. - S. 65-71.

8. Kondo S. et al. Expression of interferon regulatory factor 7 correlates with the expression of Epstein-Barr Virus latent membrane protein 1 and cervical lymph node metastasis in nasopharyngeal cancer // Pathology international. - 2017. - T. 67. - No. 9. - p. 461-466.

9. Jud A. et al. Tonsillar CD56brightNKG2A+ NK cells restrict primary Epstein-Barr virus infection in B cells via IFN- $\gamma$ // Oncotarget. - 2017. - T. 8. - No. 4. - p. 6130.

10. Ohga S. et al. Dominant expression of interleukin-10 and transforming growth factor- $\beta$ genes in activated T-cells of chronic active epstein-barr virus infection // Journal of medical virology. - 2004. - T. 74. No. 3. - p. 449-458.

11. Lünemann J. D. et al. EBNA1-specific T cells from patients with multiple sclerosis cross react with myelin antigens and co-produce IFN- $\gamma$ and IL-2 //Journal of Experimental Medicine. - 2008. - T. 205. No. 8. - p. 1763-1773.

12. Nagu T. et al. Strong anti-Epstein Barr virus (EBV) or cytomegalovirus (CMV) cellular immune responses predict survival and a favourable response to anti-tuberculosis therapy // International Journal of Infectious Diseases. - 2017. - T. 56. - p. 136-139.

13. Li Y. et al. Haemophagocytic lymphohistiocytosis in inflammatory bowel disease with virus infection // Przeglad gastroenterologiczny. - 2015. - T. 10. - No. 2. - p. 78.

14. Chinen T. et al. An essential role for the IL-2 receptor in T reg cell function // Nature immunology. 2016. - T. 17. - No. 11. - p. 1322.

15. Jiang T., Zhou C., Ren S. Role of IL-2 in cancer immunotherapy //Oncoimmunology. - 2016. - T. 5. No. 6. - p. e1163462.

16. Ben-Ami E., Miller A., Berrih-Aknin S. T cells from autoimmune patients display reduced sensitivity to immunoregulation by mesenchymal stem cells: role of IL-2 // Autoimmunity reviews. - 2014. - T. 13. No. 2. - p. 187-196.

17. Gideon H. P. et al. Variability in tuberculosis granuloma T cell responses exists, but a balance of pro-and anti-inflammatory cytokines is associated with sterilization // PLoS pathogens. - 2015. - T. 11. - No. 1. p. e1004603.

18. Wojdasiewicz P., Poniatowski Ł. A., Szukiewicz D. The role of inflammatory and anti-inflammatory cytokines in the pathogenesis of osteoarthritis // Mediators of inflammation. - 2014. - T. 2014.

19. Neurath M. F. Cytokines in inflammatory bowel disease // Nature Reviews Immunology. - 2014. - T. 14. - No. 5. - p. 329.

20. Frangogiannis N. G. The inflammatory response in myocardial injury, repair, and remodelling // Nature Reviews Cardiology. - 2014. - T. 11. - No. 5. - p. 255. 